\title{
Patterns of using places for recreation and relaxation in peri-urban areas: The case of Lake Podpeč, Slovenia
}

The paper addresses the issues of place capacity for occupancy for rest and recreation in the context of peri-urban landscapes of high natural or cultural values. It sets these issues in the frame of bottom-up approaches, considering qualitative-, small- and slow-data-oriented methods and techniques, using observation $\&$ behaviour mapping. It focuses on designing the concept of a natural site's carrying capacity and evaluating an area's carrying capacity for specific use. It proceeds from a study conducted by Goličnik Marušić (2015), which showed the prudence of addressing the development and planning of green infra- structure from the perspective of user needs and habits. By including the concept of an area's carrying capacity, it also incorporates the conservation aspect. Based on data obtained through observation and mapping, the article comments on current use and users in terms of their age, use of a place, frequency of activities, and type of activities in the case of Lake Podpeč, a popular recreational site at the fringe of Ljubljana marsh, Slovenia.

Key words: carrying capacity, green infrastructure, behaviour mapping, peri-urban landscape, spatial planning 


\section{Introduction}

This article studies the use of peri-urban landscapes for recreation, and it focuses on developing and testing the concept of an areas recreational carrying capacity. It is based on commentaries relating to the observation and behaviour mapping of spatial use patterns carried out in the pilot area examined as part of the project Landscape and Open Space Development in Alpine Metropolitan Areas (LOS_DAMA!, 2018), which was approved in the second call for project proposals within the transnational territorial cooperation programme Alpine Space 2014 -2020. The project deals with the landscape surrounding urban areas as part of wider networks of green infrastructure, which is attractive due to its natural and cultural recourses and heritage. Because of its diversity and location, it is often exposed to pressures connected with various uses. Based on concrete observations of the Lake Podpec area, a popular recreational site on the outskirts of Ljubljana, some reflections are presented on potential spatial pressures arising from the need for recreation and relaxation, and the concept of an areas's carrying capacity for specific use is defined. Behaviour observation and mapping were performed for this pilot area. As a deep sinkhole with a permanent outflow, Lake Podpeč has been protected as a geomorphological natural asset of national significance, and the wider area of the lake has been protected as a hydrological and ecosystem natural asset of national significance, which is also a natural monument. The lake's wider surroundings are part of the outer conservation area of Ljubljana Marsh Nature Park (ARSO, 2019).

Green infrastructure as an interpretation of sustainable and climate-change adaptation in spatial planning presents diverse opportunities to mediate adverse effects while simultaneously delivering environmental, economic, and social benefits, including human health and well-being, to contemporary urban dwellers. Over the past decades, the concept has largely become established as a counterweight to grey infrastructure (i.e., the built environment). Its role first and most pronouncedly came to the fore in relation to mitigating urban climate change (e.g., Gill et al., 2007). In terms of content and technology, just like in spatial planning in general, a GIS-based approach became widely established for keeping a record of green infrastructure elements, with an emphasis on interpreting data on planned use and morphological characteristics (e.g., Chang et al., 2011). Recently, after many studies demonstrating the positive role played in human health by natural or green open urban spaces (e.g., Ward Thompson, 2013), this role has also been transferred to green infrastructure. After the increasing establishment of the concept of ecosystem services, the understanding of green infrastructure as the bearer of individual aspects of ecosystem services (i.e., its mainte- nance, regulatory, cultural, and support roles) is also on the rise, calling for a multidisciplinary approach to address green infrastructure (e.g., Tzoulas et al., 2007; Taylor \& Hochuli, 2017), as well as to assess the multifunctional role of green infrastructure for maximizing ecosystem services (Meerow \& Newell, 2016).

In the face of increasing justifications of the importance of biodiversity, nature protection, and spatial planning through the concepts of green infrastructure (e.g., European Commission, 2013, 2016), ecosystem services (e.g., European Commission, 2018), and nature-based solutions (e.g., Raymond et al., 2017), from the spatial planning perspective it is key to establish new mechanisms and not only look at spatial elements from the viewpoint of their physical form and classification into grey, blue, or green infrastructure, but also to understand this as a system of natural and human processes as suggested, for example, by Goličnik Marušić and Praper Gulič (2018). Similarly, Parker and Zegoni de Baro (2019) reason that green infrastructure's focus could be expanded to consider broader contexts that may be associated with green infrastructure.

Accordingly, this article discusses green infrastructure at the fringe of these broader contexts associated with it; that is, in terms of its appeal for recreational use. Selected elements of green infrastructure are not elucidated directly in terms of their morphological, structural, or ecological characteristics; instead, the article focuses on interpreting these places from the viewpoint of the recreational activities they encourage or generate. Such an approach to understanding or examining green infrastructure is new, and it is directly related to the hypothesis stated in this research: the type, frequency, intensity of use, and its dimensions can address the carrying capacity of a place and thereby reflect the occupancy volume of a recreation site that the place or natural surroundings can sustain indefinitely.

\section{Methodology and data}

Based on the observation and behaviour mapping method (e.g., Goličnik \& Ward Thompson, 2002; Goličnik, 2006), in advance the authors produced the observation schedule and protocol, selected the observation recording method, and prepared the symbols and maps for recording the observations. The observations and behaviour recording were carried out from 9 June to 3 July 2018, which is when the school year ended and the summer holiday began, and on 19 August, when the summer holiday was drawing to an end. The entire day was divided into sequences of morning and afternoon observations. Morning observations were performed from $10 \mathrm{am}$ to $1 \mathrm{pm}$, and afternoon observations were carried out from $2 \mathrm{pm}$ 
Table 1: Coding system for entering manually collected data into ArcGIS software.

\begin{tabular}{|c|c|c|c|c|}
\hline \multirow[b]{2}{*}{ Variable } & \multicolumn{2}{|c|}{ Point entries } & \multicolumn{2}{|c|}{ Polygon entries } \\
\hline & Code & Description/class & Code & Description/class \\
\hline \multirow{12}{*}{ Activity } & 1 & Boating & 1 & Boating \\
\hline & 2 & Walking & 2 & Walking \\
\hline & 3 & Dog walking & & \\
\hline & 4 & Playing & 4 & Playing \\
\hline & 5 & Bicycling & & \\
\hline & 6 & Lying & 6 & Lying \\
\hline & 7 & Swimming & 7 & Swimming \\
\hline & 8 & Fishing & 8 & Fishing \\
\hline & 9 & Sitting & 9 & Sitting \\
\hline & 10 & Sitting with a dog & & \\
\hline & 11 & Standing & 11 & Standing \\
\hline & & & 12 & Picnicking \\
\hline \multirow{7}{*}{ Age } & 1 & $\leq 5$ years $=$ child $/$ family & 4 & Family \\
\hline & 2 & $6-12$ years $=$ child $/$ family & 4 & Family \\
\hline & 3 & $13-19$ years $=$ teenager & 1 & Teenager \\
\hline & 4 & $20-34$ years $=$ young adult & 2 & Young adult \\
\hline & 5 & $35-50$ years $=$ young adult & 2 & Young adult \\
\hline & 6 & $51-65$ years $=$ older adult & 3 & Older adult \\
\hline & 7 & $>65$ years $=$ older adult & 3 & Older adult \\
\hline \multirow{4}{*}{ Sex } & 1 & Male & 1 & Group of men \\
\hline & 2 & Female & 2 & Group of women \\
\hline & & & 3 & Mixed group \\
\hline & & & 4 & Family \\
\hline \multirow{4}{*}{ Group size } & & & 3 & 3 people \\
\hline & & & 4 & 4 people \\
\hline & & & 5 & 5-10 people \\
\hline & & & 6 & 10 people or more \\
\hline \multirow{6}{*}{ Part of day } & 1 & $10 \mathrm{am}-12$ noon & 1 & $10 \mathrm{am}-12$ noon \\
\hline & 2 & 12 noon - 2 pm & 2 & 12 noon - 2 pm \\
\hline & 3 & $10 \mathrm{am}-2 \mathrm{pm}$ & 3 & $10 \mathrm{am}-2 \mathrm{pm}$ \\
\hline & 4 & $2 p m-5 p m$ & 4 & $2 p m-5 p m$ \\
\hline & 5 & $5 p m-7 p m$ & 5 & $5 p m-7 p m$ \\
\hline & 6 & $2 p m-7 p m$ & 6 & $2 p m-7 p m$ \\
\hline \multirow{2}{*}{ Part of week } & 1 & Mon -Fri & 1 & Mon -Fri \\
\hline & 2 & Saturday -Sunday / holiday & 2 & Saturday -Sunday / holiday \\
\hline \multirow{4}{*}{ Weather } & 1 & Sunny & 1 & Sunny \\
\hline & 2 & Partly cloudy & 2 & Partly cloudy \\
\hline & 3 & Cloudy & 3 & Cloudy \\
\hline & 4 & Rainy & 4 & Rainy \\
\hline \multirow{5}{*}{ Temperature } & 1 & $15-19^{\circ} \mathrm{C}$ & 1 & $15-19^{\circ} \mathrm{C}$ \\
\hline & 2 & $20-24^{\circ} \mathrm{C}$ & 2 & $20-24^{\circ} \mathrm{C}$ \\
\hline & 3 & $25-29^{\circ} \mathrm{C}$ & 3 & $25-29^{\circ} \mathrm{C}$ \\
\hline & 4 & $30-34^{\circ} \mathrm{C}$ & 4 & $30-34^{\circ} \mathrm{C}$ \\
\hline & 5 & $\geq 35^{\circ} \mathrm{C}$ & 5 & $\geq 35^{\circ} \mathrm{C}$ \\
\hline
\end{tabular}



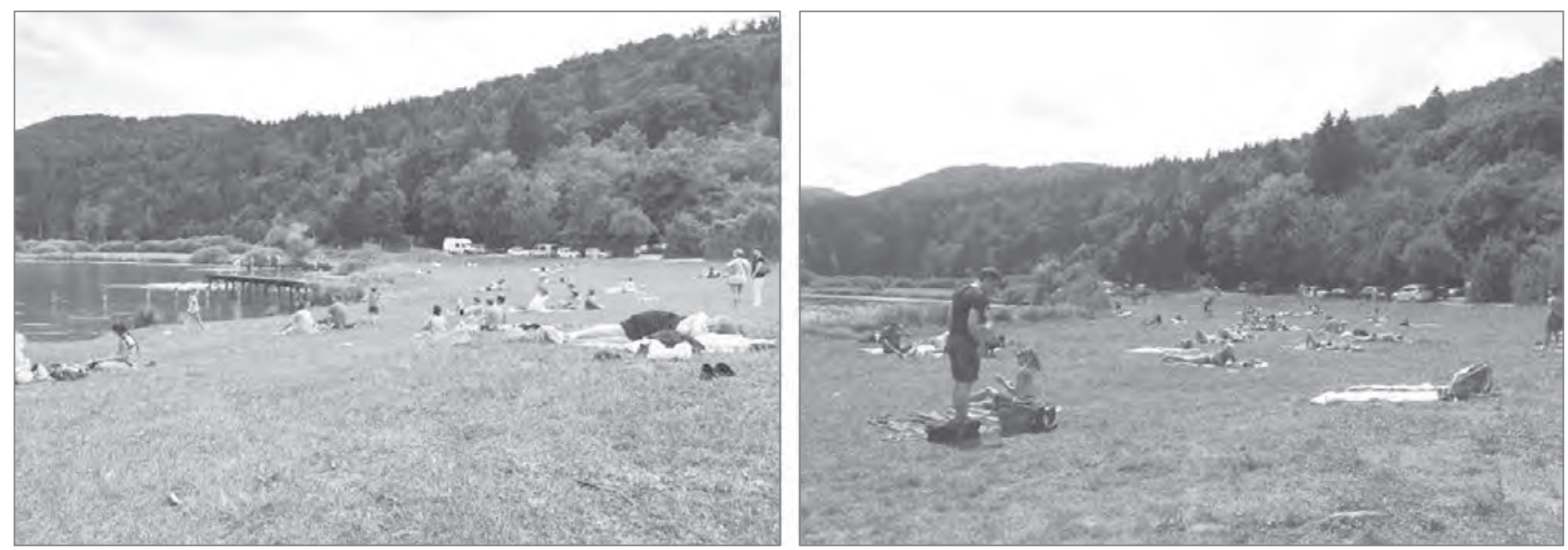

Figure 1: High place occupancy: Visitors to the lake on 17 June 2018; and visit at midday on 19 August 2018 (photo: Manca Dremel).
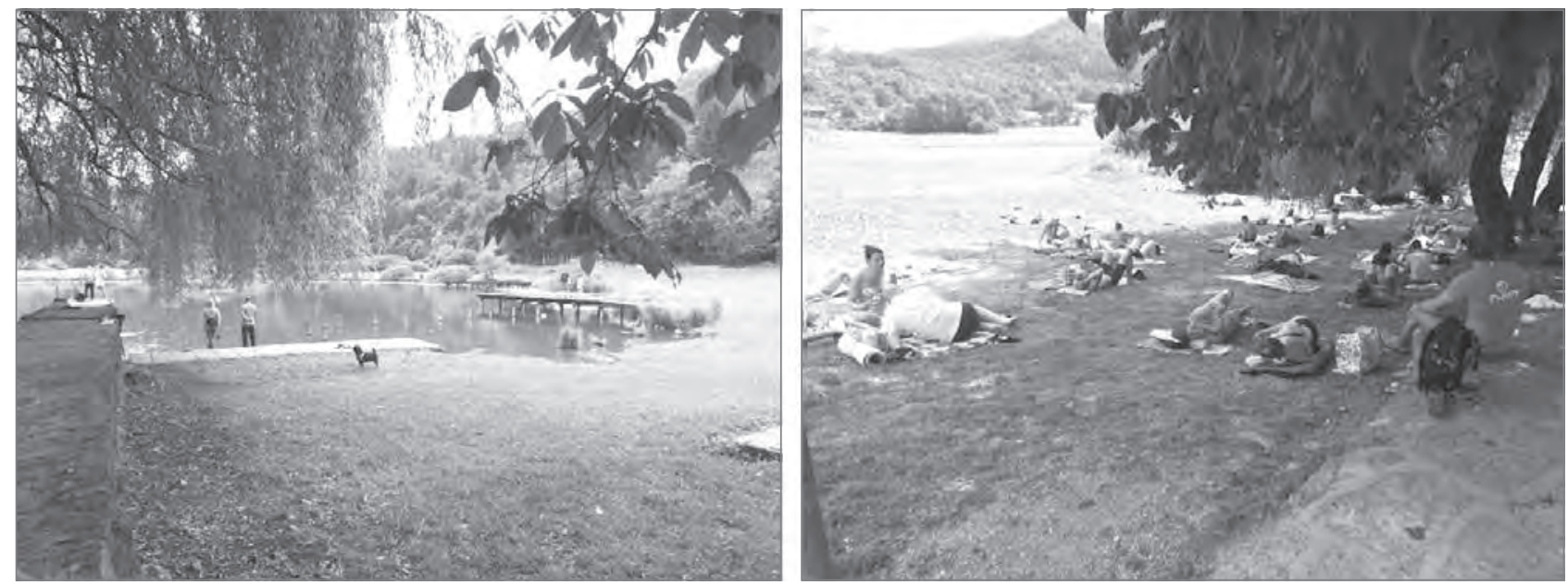

Figure 2: Contrast between low and high occupancy: Visit during poor weather, 29 June 2018; Looking for shade, 19 August 2018 (photo: Manca Dremel).

to $7 \mathrm{pm}$. At Lake Podpeč, where the structural and morphological characteristics of the area make it possible to observe the entire area of use at once, an individual observation, which entails glancing over the area to estimate users' age, sex, and activity, lasted thirty minutes. Based on the observation intervals twenty-eight observations were performed. Afternoon observations were often interrupted or made impossible by summer storms. Observations were planned to be carried out on both weekdays and weekends, but initial observations showed that in terms of visit intensity it was key to obtain weekend data. The final shares of observation days at Lake Podpeč were as follows: four weekend days and six weekdays. The results of observations performed at Lake Podpeč are presented in detail below and commented on four days with significant numbers of visitors.

Observation data were captured manually, in which individuals or couples were recorded as point symbols expressing the user's type of activity and sex. They were additionally furnished with codes for the age group an individual belonged to and for the time of stay or the duration of the spatial activity. If the activity involved three or more individuals, the areas of the groups were mapped, with symbols denoting the type of activity and codes for the group's composition (age and sex) and size (the number of individuals in a group) added. In addition to basic records on visitors' activity, location, time of stay, age, and sex, data explaining other circumstances were also gathered for all variables (individuals and groups): the part of the day and week, and basic information on the weather. OpenStreetMap material formed the cartographic basis for creating the behaviour maps, and ArcGIS (by Esri) software was used to convert the manually collected data into digital form. Individuals were entered as point-type variables and groups as polygon-type variables. Every entry was ascribed an identification number and was coded according to the coding system presented below.

\section{Analysis}

The current recreational use was analysed and commented on in terms of a set of parameters that can determine or char- 
acterize people's use of places. The basic descriptive analyses derive from the data directly collected and comment on the use of places in terms of the number of visitors, the type of socializing (individually, as a couple, or in a group), the time of visit (morning, afternoon, weekend, or weekdays), and the visitors' age group (children, teenagers, young adults, older adults, and the elderly). Other derived data, such as the type of activity (actual and performed in groups: active, passive, or performed while passing through the place), the manner of occupying a place (how; locations and distances between user(s) or user groups; the place filled up by visitors), the frequency of activities (frequent, occasional, or rare), and their intensity (the number of people involved in the same activity), were important for generating the concept of a place's carrying capacity for recreational use. The findings of these analyses are presented in the three subsections below.

\subsection{Basic descriptive analyses}

The largest number of visitors to Lake Podpeč were recorded on Sunday, 17 June 2018, when the observation and mapping were performed in the afternoon ( $2 \mathrm{pm}$ to $7 \mathrm{pm}$ ) and on Sunday, 19 August 2018, when the behaviour observation and mapping were carried out in the morning (10 am to $2 \mathrm{pm}$ ). In both cases, approximately three hundred people were recorded in the area observed. Comments on the two selected days are presented comparatively to other days or in terms of the intensity and characteristics of weekend visits.

The cumulative behaviour map of people's use of places on all the days observed shows the locations of the places used for both individuals (point symbols) and groups (a simplified presentation using circles of various sizes). The cumulative behaviour map shows people's use of places and the spatial distribution of uses on all the days observed, drawing attention to the extent of pressure on the area in terms of the density and intensity of uses. The map clearly shows which parts are used more and which are used less, forming the basis for further analyses of the actual uses, their intensity, frequency, compatibility, and so on.

A detailed analysis of activities at Lake Podpeč showed that most visitors tend to sit on the grassy edge of the lake on both weekdays and weekends, and that the second most frequent activity is lying in the grass on weekends and taking walks on weekdays. Something similar is also confirmed by the analysis of people's use of places when it comes to groups (three or more people together): the largest number of groups were seen sitting, swimming, or walking. A comparison of people's use of places on weekends and weekdays shows that among water activities swimming is more common on weekends and fishing on weekdays.

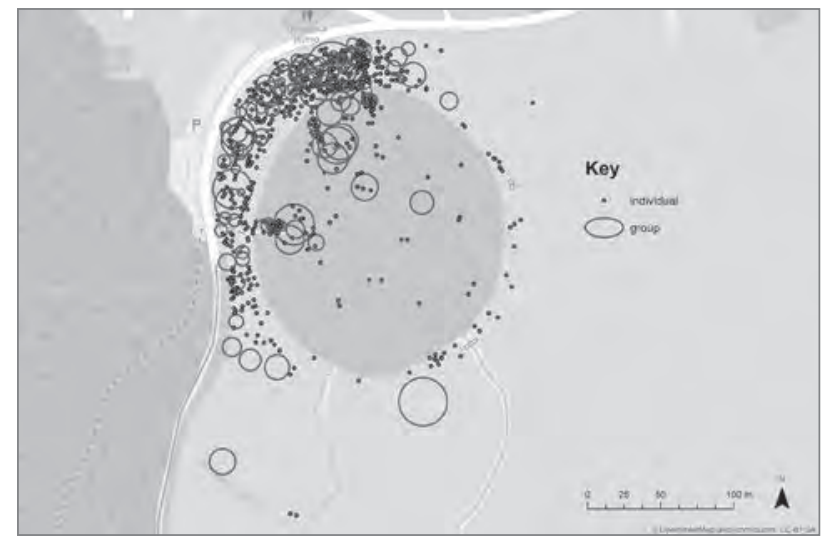

Figure 3: Cumulative behaviour map for Lake Podpeč, June -August 2018 (illustration: Nevenka Mihevc, source: OpenStreetMap and field data).

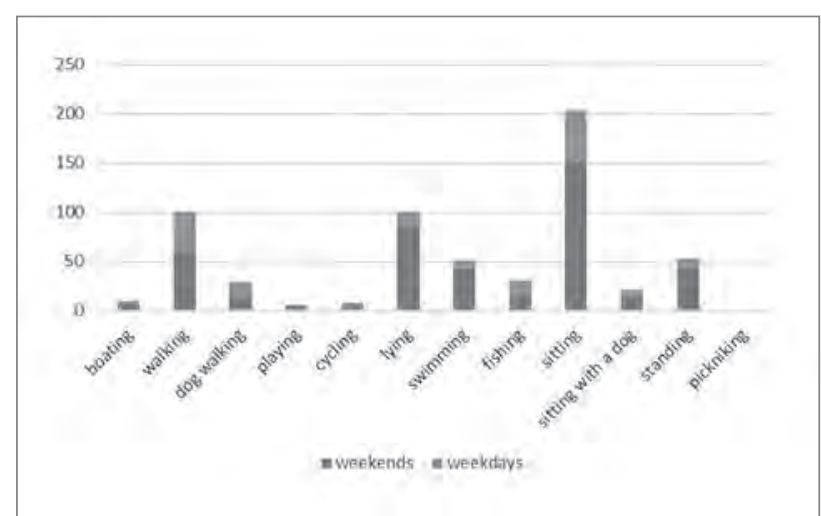

Figure 4: Number of visitors by activity over the entire observation period (illustration: Barbara Goličnik Marušić).

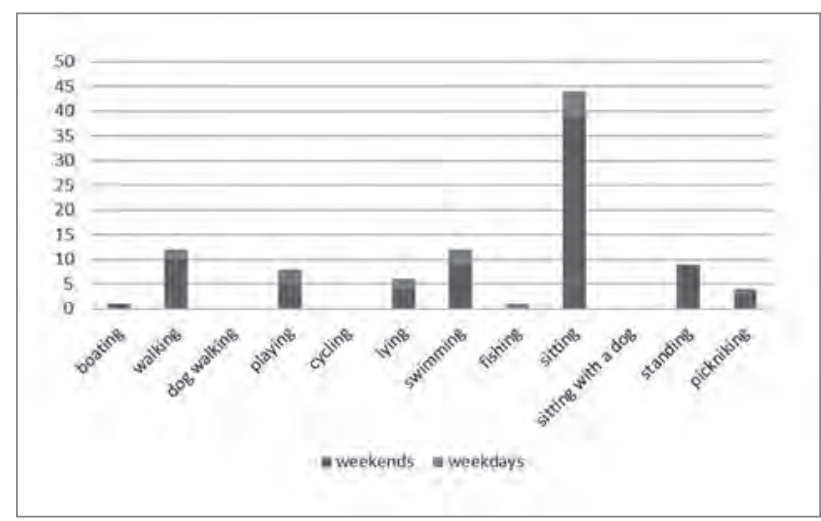

Figure 5: Number of groups (regardless of size) over the entire observation period (illustration: Barbara Goličnik Marušić).

In addition to determining the cumulative effects of pressures on an area, it is also important to identify how the area is being used or filled up. The characteristics of filling up the place during the day are confirmed by the data on people's use of the place on low-visit days, based on which it can be concluded that the place is used sequentially. Figure 6 compares low-visit days ( $\mathrm{a}$ and $\mathrm{b}$ ) with a peak day (c). Due to the characteristics and layout of the place, the areas close to the 


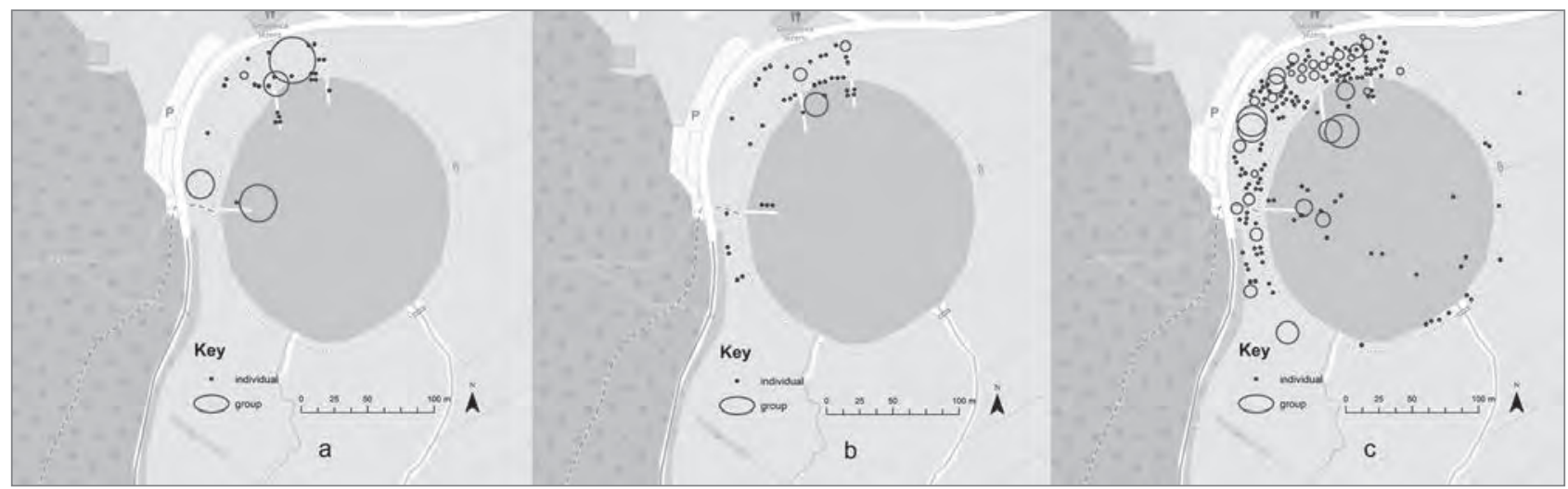

Figure 6: Ways of filling up the place based on use recorded on three different days: a) 15 June 2018, b) 26 June 2018, and c) 17 June 2018 (illustration: Nevenka Mihevc, source: OpenStreetMap and field data).

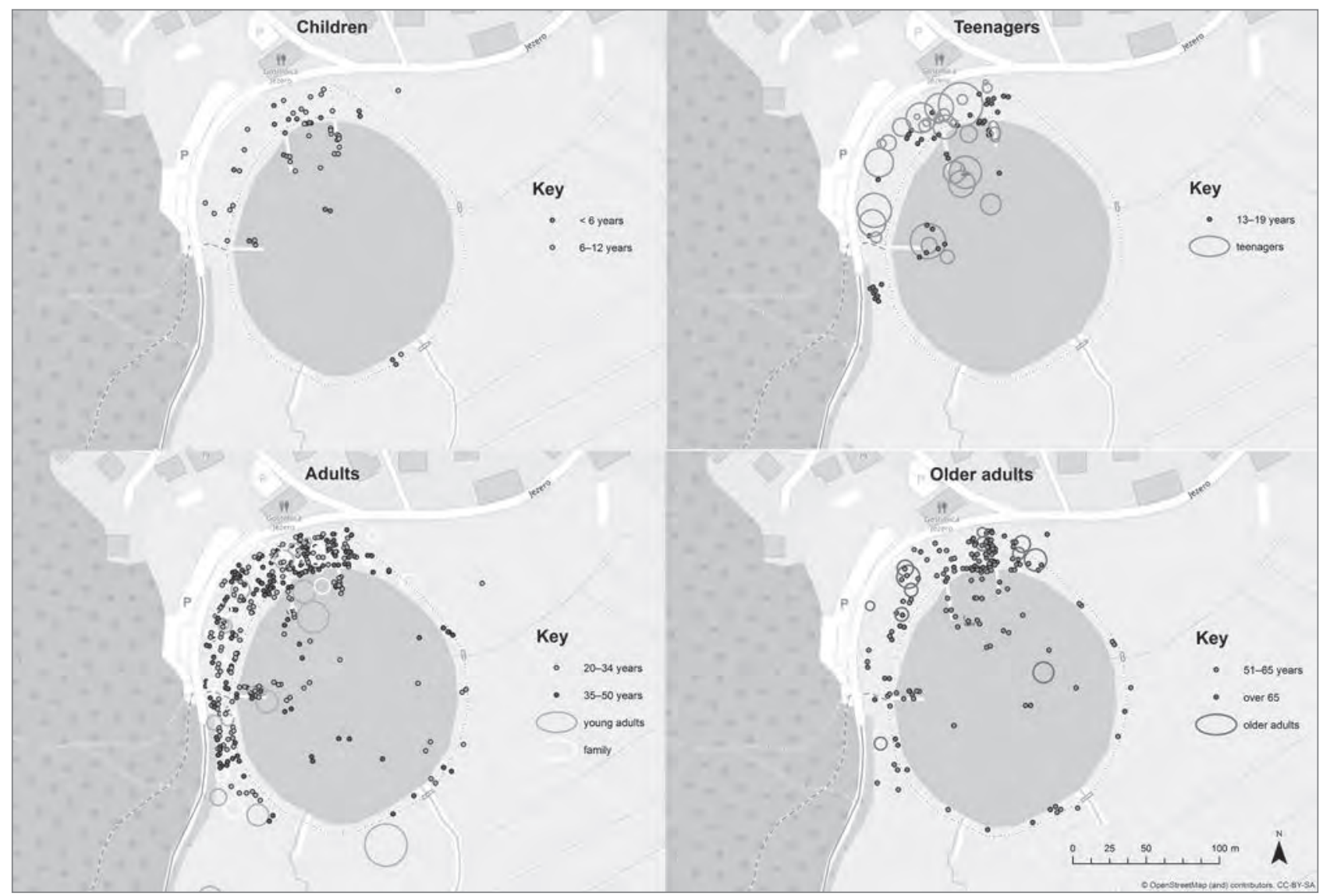

Figure 7: People's use of the place by age group (illustration: Nevenka Mihevc, source: OpenStreetMap and field data).

piers and those that offer shade are filled up first, after which the area between the two piers starts to slowly fill up as well. Figure $6 c$ shows that when the area between the piers fills up to the extent allowing users to still feel comfortable, the western edge of the lake begins to gradually fill up as well, followed by the southern edge (predominantly with activities that do not last long).

The analyses show that Lake Podpeč is a popular destination for all age groups. Teenagers predominantly go there in large groups and engage in both shore and water activities as a group. Families make up the smaller groups observed in the area. Further analysis shows that children under six usually do not move away from the place where the family is staying or are always accompanied by adults. Young adults (20 -34 years) and families usually come in smaller groups. In turn, older adults (51 -65 years) also come in large groups and, interestingly, they come to Lake Podpeč to swim vigorously. People over 65 usually take walks. 


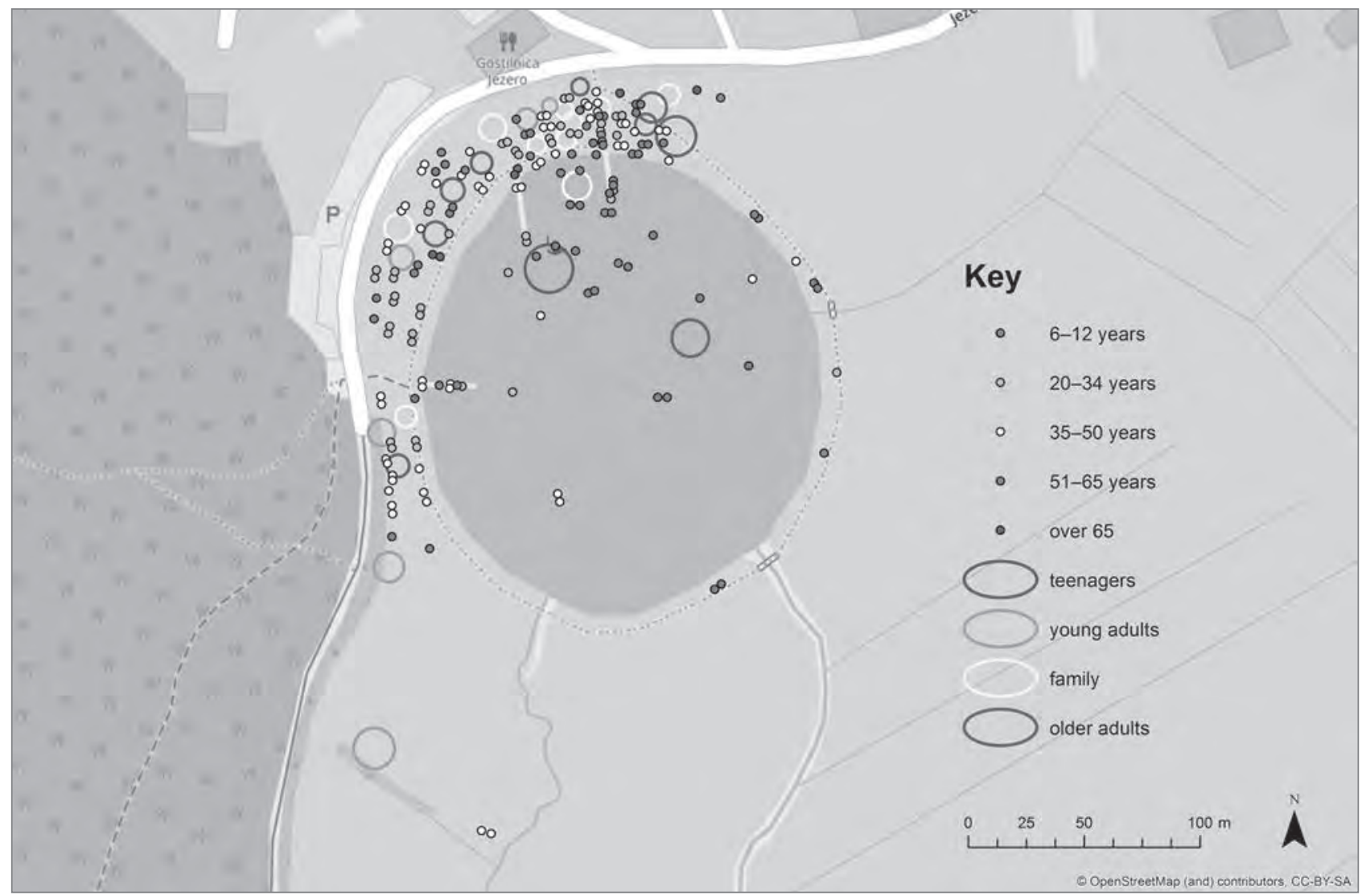

Figure 8: People's use of the place on a typical day (illustration: Nevenka Mihevc, source: OpenStreetMap and field data).

A typical day at Lake Podpeč shows that families and older adults tend to linger in the shade on the northern shore. Young adults are evenly distributed from the shady part to the southern part of the western lake shore, either individually or in groups, and older adults swim the most. The edge of the lake overgrown with natural vegetation is used for walks around the lake, but not for other, longer activities.

\subsection{Type of activities}

Data analyses were performed, using a method adapted from Goličnik (2007), according to which activities were divided into three groups: active outdoor activities (i.e., active presence in a place such as playing with a ball), passive outdoor activities (i.e., passive presence in a place such as lying down or sitting), and activities performed while passing through the place (i.e., transition through a place such as jogging or walking). The analyses show that active outdoor activities at Lake Podpeč are mainly tied to the water environment: swimming and playing in the water. With regard to active and constantly present shore activities, certain groups were observed that had picnics on the shore and engaged in ball games or tag (children). To illustrate this, Figure 10 presents behavioural patterns of using the place by activity on the afternoon of Sunday, 17 June 2018, and on the morning of Sunday, $19 \mathrm{Au}-$ gust 2018.

\subsection{Frequency and intensity}

Further analyses focused on the frequency of a specific activity and the assessment of intensity of its pressure on the environment. Frequent activities are considered those that were recorded on over $66 \%$ of observation days, occasional activities are those that occurred in 33 to $66 \%$ of observations, and rare activities are those recorded in fewer than $33 \%$ of observations. The analysis shows that water activities between the north piers and along the western pier, and activities on the level banks of the lake's western edges are frequent. This area is thus practically always used, and it is currently used for both passive and active activities. The map showing active individuals indicates that people tend to sit or lie on the grass closer to the water's edge (on the banks between the piers).

A basic analysis of the maps shows which parts are usually used for frequent activities and which ones for rare activities, which consequently indicates which micro locations can be expected to be under greater pressure. Comparing the maps also shows that occasional and always expected or frequent activities are common on days with lots of visitors, and that other activities in addition to these are common on days when visits are low. The frequency analysis is important because it reveals that not only expected and usual activities (i.e., those 


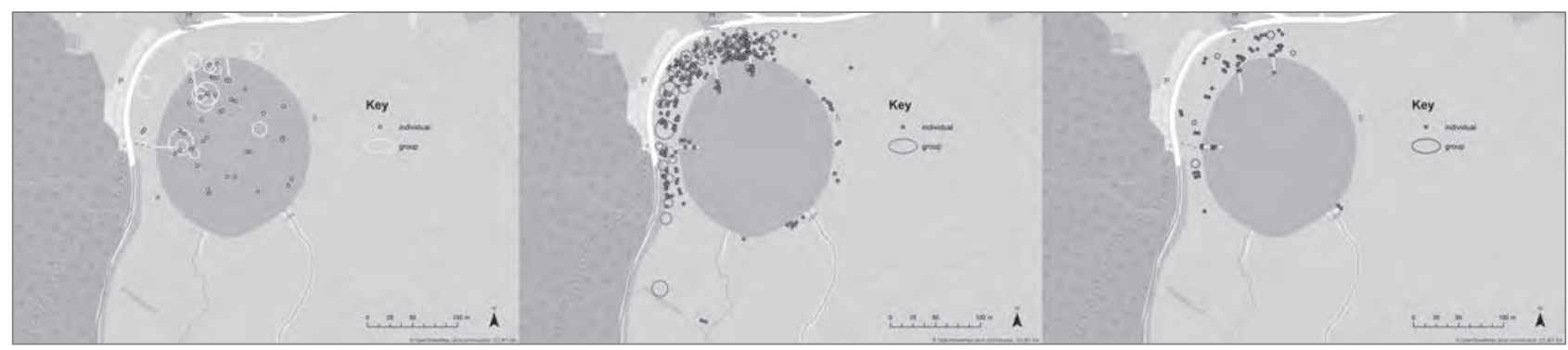

Figure 9: Examples of cumulative use of the place by type of activity during peak days (15 June 2018, 17 June 2018, and 19 August 2018; illustration: Nevenka Mihevc, source: OpenStreetMap and field data).

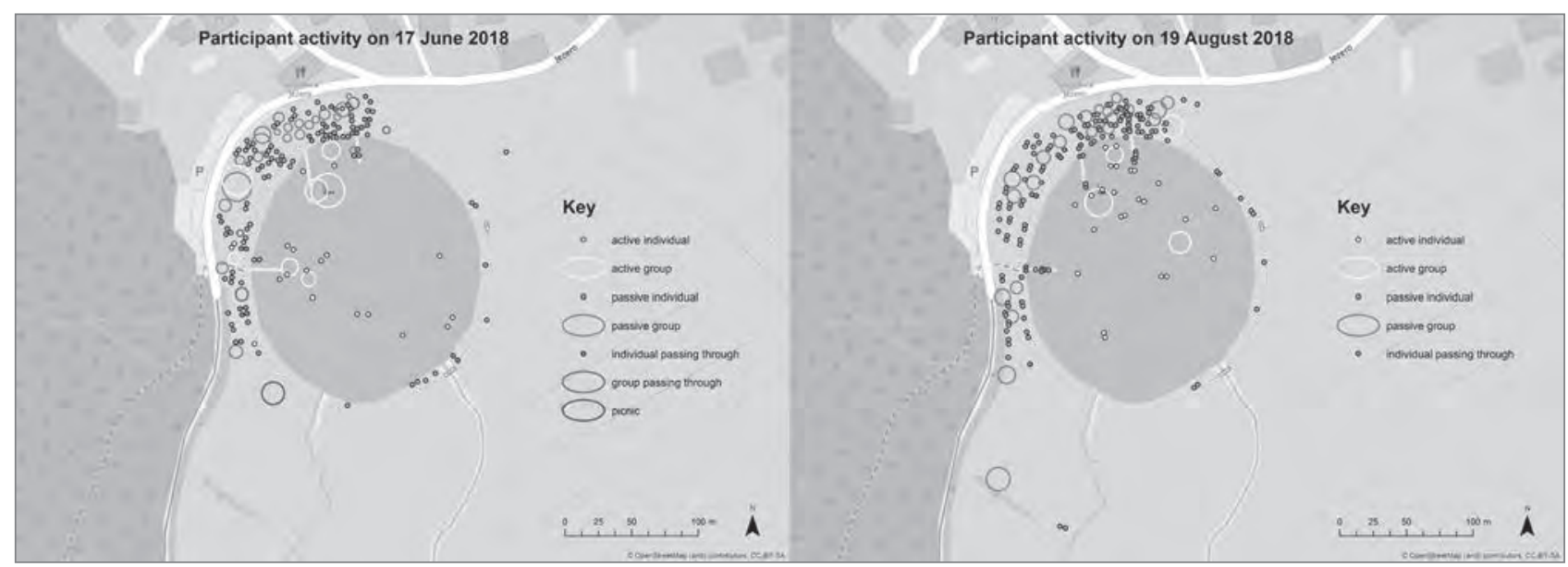

Figure 10: Single-day behavioural patterns of using the place by activity (illustration: Nevenka Mihevc, source: OpenStreetMap and field data).

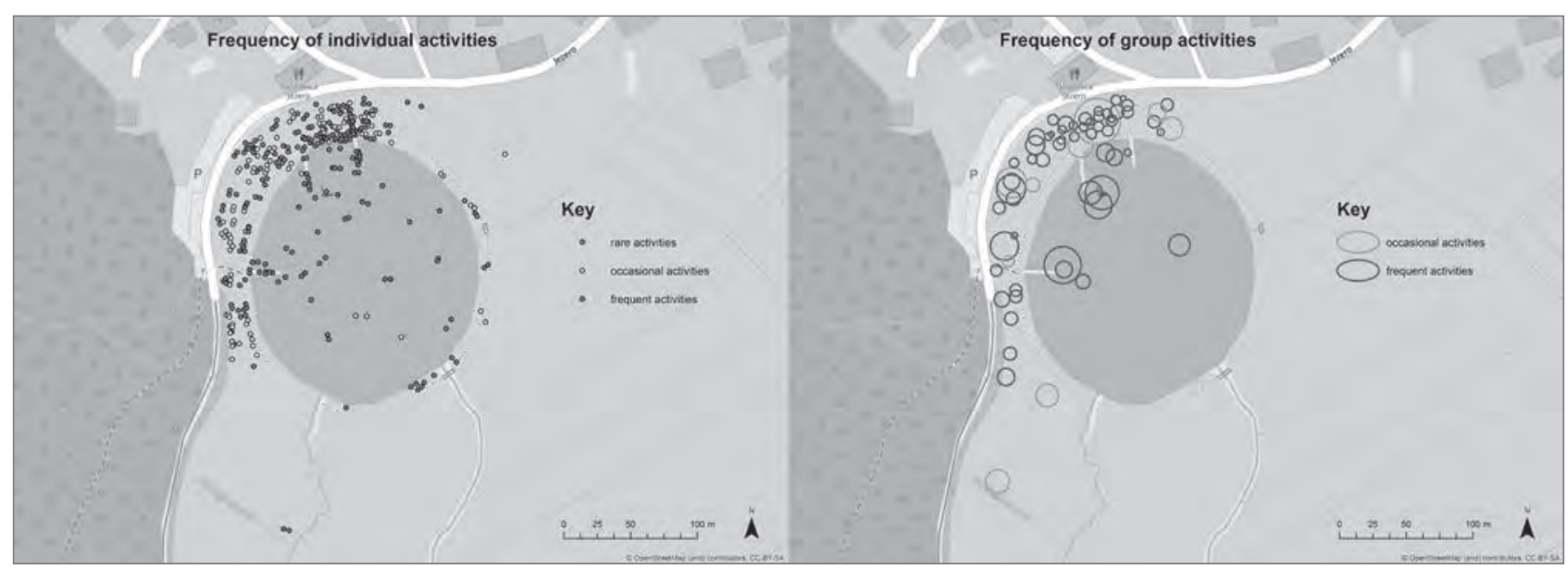

Figure 11: Frequency of users at Lake Podpeč: a) individuals, b) groups (illustration: Nevenka Mihevc, source: OpenStreetMap and field data).

that are expected because they are usually frequent), but also other less expected activities are present in the area, and that there is a need for them. Analyses can reveal which activities these are and what relation they have to the frequent activities. This is especially important when comparing the frequency of weekday and weekend activities because it turns out that occasional or rare activities are the ones that are more likely to be observed on weekdays and that they are more likely to involve local residents rather than tourists or visitors from afar.
Within this context, a detailed analysis of the days observed showed that Lake Podpeč is not necessarily a final cycling destination, but that recreational cyclists occasionally stop there and then continue on their way: cyclists were rarely spotted during the week and only occasionally on weekends. Analyses also showed that Lake Podpec is a distinctive destination for lingering; this means that frequently observed activities are characterized by the fact that they are constantly present in the area, either as passive (e.g., sitting) or active (e.g., swimming). A separate comparison of the frequency of activities only in 


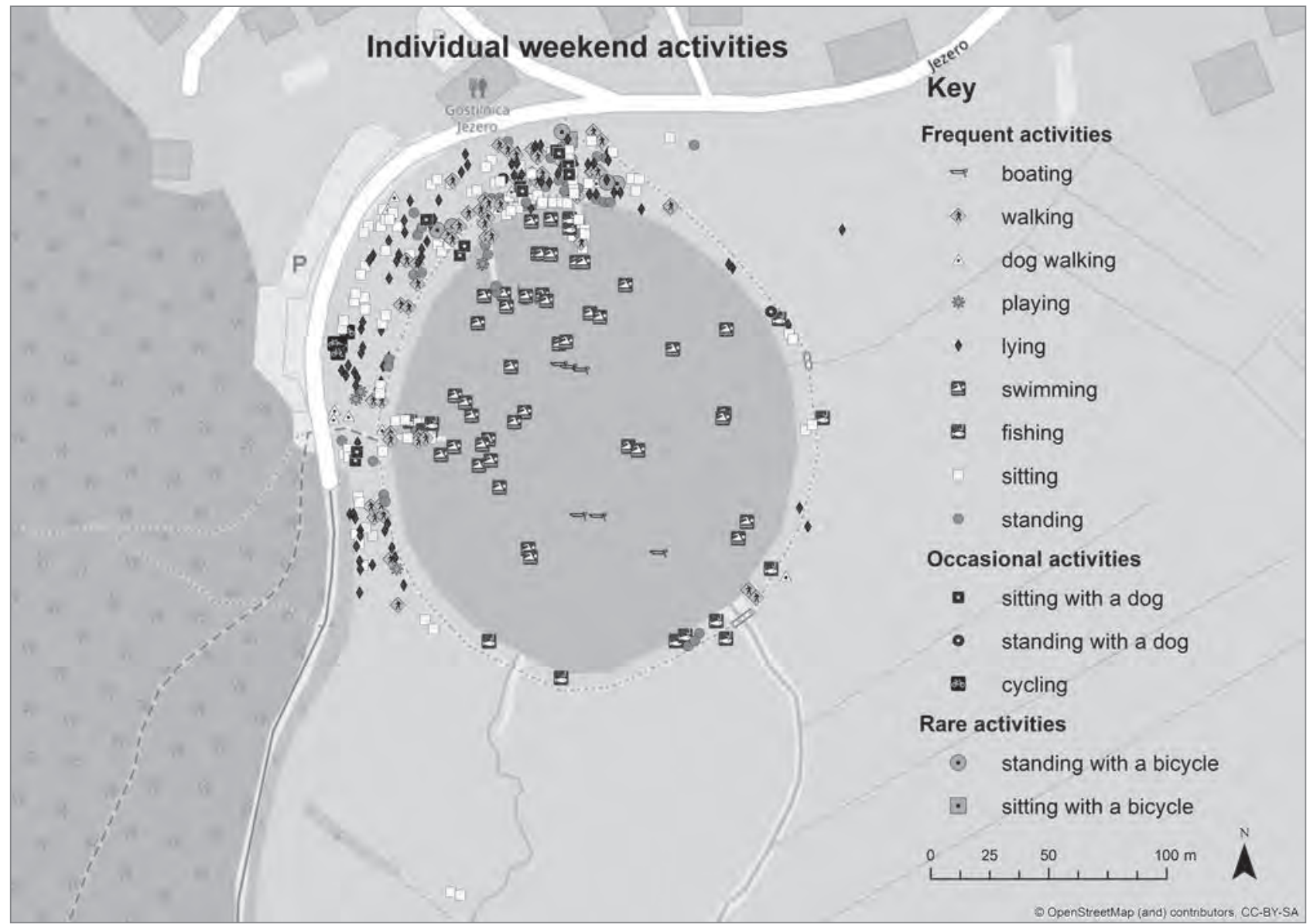

Figure 12: Type of activity by weekend frequency (illustration: Nevenka Mihevc, source: OpenStreetMap and field data).

terms of activities observed on weekends shows that the same types of activities typically occur on weekends, which is why many of them are frequent.

\section{Results}

This section is based on the analyses presented, and it interprets the results to make it possible to define the concept of green infrastructure from the viewpoint of cultural ecosystem services that take into account the vulnerability of a specific area or natural environment.

\subsection{The area's carrying capacity for recreational use}

Based on the analyses presented above, a general estimate of the recreational carrying capacity of this high-value landscape was established. The empirical results showed that, in areas of intensive use with frequent long-lasting active or passive activities, the average land area per user was at least $30 \mathrm{~m}^{2}$ or, for the generalized size of the area, if users were evenly distributed, everyone would use or occupy a piece the size of a circle with at least a three-metre radius.
The data showed that on peak days there are approximately three hundred people in the Lake Podpeč area and that they stay there for at least a few hours. The area they use (AU) ranges from $3,500 \mathrm{~m}^{2}$ (an area of denser use) to $8,000 \mathrm{~m}^{2}$ (an area with uses dispersed on the edges). The two areas calculated differ regarding the distribution of users in the place. The larger area includes all locations used any time within the entire observation period (i.e., the most scattered pattern of cumulative use of place), whereas an area of denser use refers to an area usually occupied, excluding more distant locations that may sometimes be selected for any use; for example, sitting or fishing (see Figure 13).

$$
C=\frac{A U}{N U} ; C=\pi r^{2}
$$

where:

$A U=$ total area used

$N U=$ number of people in the total area used

$C=$ generalized size of the area used per person

$r=$ radius of the generalized size of the area used per person

$C 1=\frac{3,500 \mathrm{~m}^{2}}{300}=12 \mathrm{~m}^{2} ; C 1=12 \mathrm{~m}^{2}=\pi r^{2}, r=\sqrt{\frac{o 1}{\pi}}, r=\sqrt{3.8} \sim 1.9 \mathrm{~m}$

$C 2=\frac{8,000 m^{2}}{300}=26 \mathrm{~m}^{2} ; C 2=26 \mathrm{~m}^{2}=\pi r^{2}, r=\sqrt{\frac{02}{\pi}}, r=\sqrt{8.2}-2.8 \mathrm{~m}$ 


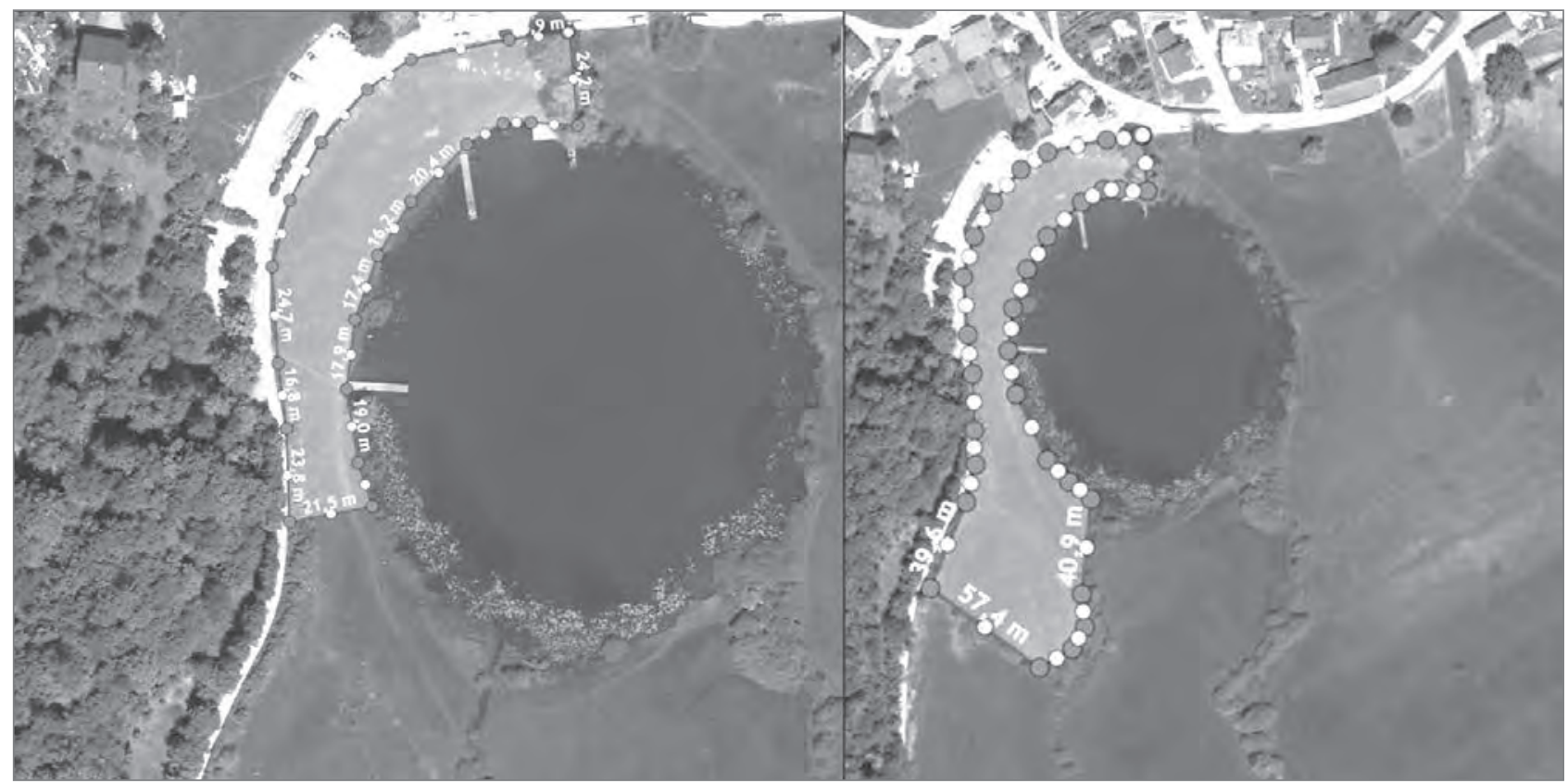

Figure 13: Two areas selected for calculating carrying capacity (illustration: Nevenka Mihevc, source: Agencija Republike Slovenije za okolje, Atlas okolja). Estimates showed that every person uses an area of the size of a circle (C) with a two-to-three-metre radius.

\subsection{Discussion}

The current level of development of the concept of an area's carrying capacity for specific use only involves rough assessments, but it is important that such topics begin to be addressed and discussed in order to develop an idea of actual uses and their impacts on the environment, and the environment's natural regeneration capacity. For illustration, in addition to the frequency of a specific activity, its intensity (i.e., how many people are involved in the same type of activity at the same time in the area observed) is vital to suitably assess the area's carrying capacity for leisure and recreational uses. Activities observed on weekends that usually involved a larger number of people included sitting, lying on the grass, and swimming. Frequent, but not very intensive activities (i.e., involving fewer people) were also fishing, watching or standing around, and walking.

Despite everything, such assessments can thus provide a good starting point for seeking answers (or posing new questions). Estimates such as those illustrated above form the basis for further thinking and designing action plans and measures for directing recreational and relaxational activities to a specific area. In addition, they can help predict the capacities for the new locations to which such uses are being directed and site the relevant activities in these locations. Moreover, they also help redistribute and direct recreational users to similar areas or contribute to the sustainable management of protected areas from the perspective of recreation and visits.

Based on these results, the extent of pressure that still ensures adequate privacy in public space can be determined (Hall, 1966).
For example, the abstract area of influence (a generalized area with a two-to-three-metre radius per person) occupied by an individual in the pilot case presented here roughly matches the anthropology of space (Hall, 1966) corresponding to "social distance - far phase", which, according to Hall (1966), ranges from 2.1 to $3.7 \mathrm{~m}$.

These initial estimates provide a preliminary starting point for further research into the potential of the concept of an area's carrying capacity for specific use not only from the viewpoint of an area's social dimensions, but also nature protection and biodiversity. The results of the pilot study showed that the southern part of the lake is less attractive for sitting or lying on the grass. It is overgrown, damp, without shade, and crisscrossed by well-trodden paths, which are only some of the reasons for visitors not spending a long time there. However, it performs an important ecosystem and biodiversity function. It is thus important to highlight the fact that, in terms of the carrying capacity of the lake's wider area, it makes sense to continue to have people stay on one end, so that the southern part can perform its natural function. In terms of environmental pressure, it would be inappropriate to introduce solutions for developing the southern part and making it available for use.

\section{Conclusion}

Based on the established observation and behaviour mapping method, this article presents findings about the basic characteristics of spatial uses at Lake Podpeč, commenting on the features of activities' distribution across the area in terms of 
various parameters: density of use and manner of filling up the area, activity type and intensity, presence by age group, and so on. It introduces the concept of an area's carrying capacity for use as a new quantity for determining pressure on the environment through use. In addition to a range of social pressures on the environment, it is also vital to identify opportunities and limitations of areas in terms of use, especially for areas recognized as high-value natural or cultural landscapes because as such they are even more attractive for use. Based on pilot studies, a draft concept was developed and the first empirical measurements were conducted. The first assessments of an area's carrying capacity based on a generalized size of the area used per person are only the beginning. The more similar observations and analyses following the proposed protocol are performed in the future, the more likely improved measures for determining the rate of an area' carrying capacity for use will be obtained. It will be necessary to study the relationship between an area's use, its physical form, and ecosystem features in as multi-layered a manner as possible.

Barbara Goličnik Marušić

Urban Planning Institute of the Republic of Slovenia, Ljubljana,

Slovenia

E-mail: barbara.golicnik-marusic@uirs.si

Nevenka Mihevc

Institute of the Republic of Slovenia for Nature Conservation, Ljubljana, Slovenia

E-mail: nevenka.mihevc@gmail.com

\section{Manca Dreme}

University of Ljubljana, Biotechnical Faculty, Department of Biology,

Ljubljana, Slovenia

E-mail: manca.dremel@gmail.com

\section{Acknowledgments}

The research presented in this article was conducted as part of the project Landscape and Open Space Development in Alpine Metropolitan Areas (LOS_DAMA!), which was approved in the second call for project proposals within the transnational territorial cooperation programme Alpine Space 2014-2020, and the research project P5-0100 - Spatial Planning, co-funded by the Slovenian Research Agency from the national budget. Some premises also derive from the project J5-7178 - Integral System of Flood Sustainable Spatial Planning, also co-financed by the Slovenian Research Agency from the national budget.

\section{References}

ARSO (2019) Agencija Republike Slovenije za okolje, Atlas okolja. Available at: http://gis.arso.gov.si/atlasokolja/profile.aspx?id=Atlas_Okolja_AXL@Arso (accessed 13 June 2019).

Chang, Q., Li, X., Huang, X. \& Wu, J. (2011) A GIS-based green infrastructure planning for sustainable urban land use and spatial development. Procedia Environmental Sciences, 12(2012), 491-498. DOI: 10.1016/j. proenv.2012.01.308
European Commission (2013) Communication from the commission to the European Parliament, the Council, the European Economic and Social Committee and the Committee of the Regions: Green Infrastructure (GI) - Enhancing Europe's Natural Capital. Available at: http: eur-lex.europa.eu/resource.html?uri=cellar:d41348f2-01d5-4abe-b8174c73e6f1b2df.0014.03/DOC_1\&format=PDF (accessed 12 Feb. 2018).

European Commission (2016) Supporting the implementation of green infrastructure. Directorate-General for the Environment, ENV.B.2/ SER/2014/0012. Available at: http: https://ec.europa.eu/environment/ nature/ecosystems/docs/green_infrastructures/GI\%20Final\%20Report. pdf (accessed 25 Apr. 2018).

European Commission (2018) Mapping and assessment of ecosystems and their services: An analytical framework for mapping and assessment of ecosystem condition in EU. Luxembourg, Publications Office of the European Union.

Gill, S. E., Handley, J. F., Ennos, A. R. \& Pauleit, S. (2007) Adapting cities for climate change: The role of green infrastructure. Built Environment, 33(1), 115-133. DOI: 10.2148/benv.33.1.115

Goličnik, B. (2006) Vedenjski zemljevidi ljubljanskih trgov in parkov: novi izzivi in pogledi na načrtovanje in urejanje prostora. Ljubljana, Urbanistični inštitut Republike Slovenije. DOI: 10.5379/urbani-izziv-2002-13-01-011

Goličnik, B. \& Ward Thompson, C. (2002) Opazovanje in vedenjski zemljevidi: metoda raziskovanja javnega odprtega prostora $v$ mestu. Urbani izziv, 13(1), pp. 82-89. DOI: 10.5379/urbani-izziv-2002-13-01-011

Goličnik Marušić, B. (2015) Social behaviour as a basis for design and development of green infrastructure. Urbani izziv, 26, pp. 130-149. DOI: 10.5379/urbani-izziv-en-2015-26-supplement-009

Goličnik Marušić, B. \& Praper Gulič, S. (2018) Development of a user-centered module: A contribution to flood-sustainable spatial planning. Urbani izziv, 19(2), pp. 111-125. DOI: 10.5379/urbani-izziv-en-2018-29-02-004

Hall, E. T. (1966) The hidden dimension. New York, Bantam Doubleday Dell Publishing Group.

LOS_DAMA! (2019) Green infrastructure for better living. Available at: https://www.alpine-space.eu/projects/los_dama/en/ home (accessed 30 May 2019).

Meerow, S. \& Newell, J. P. (2017) Spatial planning for multifunctional green infrastructure: Growing resilience in Detroit. Landscape and Urban Planning, 159, pp. 62-75. DOI: 10.1016/j.landurbplan.2016.10.005

Openstreetmap Foundation (2019) Openstreetmap. Available at: https:// www.openstreetmap.org (accessed 12 May 2018).

Raymond, C. M., Berry, P., Breil, M., Nita, M. R., Kabisch, N., de Bel, M.(2017) An impact evaluation framework to support planning and evaluation of nature-based solutions projects. Report prepared by the EKLIPSE Expert Working Group on Nature-Based Solutions to Promote Climate Resilience in Urban Areas. Wallingford, UK, Centre for Ecology \& Hydrology.

Taylor, L. \& Hochuli, D. F. (2017) Defining greenspace: Multiple uses across multiple disciplines. Landscape and Urban Planning, 158, pp. 2538. DOI: 10.1016/j.landurbplan.2016.09.024

Tzoulas, K., Korpela, K., Venn, S., Yli-Pelkonen, V., Ka'zmierczak, A., Niemela, J. \& James, P. (2007) Promoting ecosystem and human health in urban areas using green infrastructure: A literature review. Landscape and Urban Planning, 81, pp. 167-178. DOI: 10.1016/j.landurbplan.2007.02.001

Ward Thompson, C. (2013) Activity, exercise and the planning and design of outdoor spaces. Journal of Environmental Psychology, 34, pp. 79-96. DOI: 10.1016/j.jenvp.2013.01.003 